\title{
Sampah Plastik sebagai Konsekuensi Modernitas dan Upaya Penanggulangannya
}

\author{
Alfitri, Helmi, Slamet Raharjo, Afrizal \\ Universitas Andalas \\ Email: dknfisip@gmail.com
}

\begin{abstract}
Modernization have increased the use of plastic. This causes plastic waste has become one of the most worrying global environmental problems. Poorly waste management system and unsupportive people's behaviour are the factors of plastic waste problem. Using Giddens' theory of consequence of modernity and library research, this article argues that capitalism which emphasizes packaging is one of the consequences of modernity and this responsible for the massive use of plastic, but behaviour of plastic consumers make plastic waste deteriorate environment. It is also argued that then beside innovative and efficient production,people's action that move from unconscious motivation to practical consciousness, and discursive consciousness is needed to overcome the problem. This is expected to form behaviour of the use of plastics that are more environmentally friendly.
\end{abstract}

Keywords: plastic waste management, consequences of modernity, environmental behaviour

\section{A. PENDAHULUAN}

Sejak beberapa dasawarsa yang lalu, banyak ahli dan berbagai badan dunia telah mengingatkan bahwa masalah dan tantangan global yang utama adalah lingkungan hidup. Drucker (1997: 162-163), misalnya, melihat bahwa ancaman terbesar terkait ini adalah adanya kerusakan hutan tropik yang merupakan paruparu dunia, kerusakan habitat insani, kerusakan atmosfir, berkurangnya cadangan air bersih, dan polusi atau pencemaran. Menurutnya, ini adalah masalah global yang harus diselesaikan bersama secara transnasional. Polusi merupakan masalah dan tantangan yang tak mungkin dihadapi dalam batas-batas suatu negara nasional. Sebagaimana halnya uang dan informasi, polusi tak mengenal lagi perbatasan.

Salah satu, polusi yang sekarang menjadi masalah dan keprihatinan global adalah limbah atau sampah plastik. Sebagai masalah global, sampah plastik ini perlu ditangani secara serius di setiap level dan setiap sudut dunia. Sampah plastik ini tidak hanya mengakibatkan pencemaran di darat dan lautan, tapi juga di udara karena adanya pembakaran limbah plastik yang tidak terkontrol. Karena itu, negara-negara berkembang perlu menjadikan ini sebagai prioritas utama dalam penanganan polusi (Haggar dan Hatow, 2009).

Sampah plastik telah menjadi isu global yang penting terkait dengan peningkatan populasi, urbanisasi, gaya hidup konsumtif, dan ekspansi dari produkproduk teknologi baru di lingkungan perkotaan (Mahesha dan 
Mallika, 2017). Selain itu, kecuali dari sampah rumah tangga, limbah plastik di pedesaan terutama juga banyak berasal dari aktivitas pertanian (Jalil, 2016). Sementara itu, selain berasal dari mengalirnya sampah plastik melalui sungai ke lautan, sampah-sampah plastik di lautan juga berasal dari kapal-kapal yang berlayar di lautan. (Culin dan Bielic, 2015).

Sampah plastik yang terhanyut di laut lepas dapat menjangkau daratan atau perairan di mana pun. Harian Kompas, (24 Juni 2020), misalnya, melaporkan penemuan riset adanya mikroplastik dalam usus seekor binatang di suatu pulau yang terpencil yang tidak berpenghuni di Antartika. Para peneliti dari University of Siena dan University of Dublin tersebut menunjukkan bahwa itu merupakan bukti berbasis lapangan pertama adanya kontaminasi mikroplastik pada hewan Antartika. Ini sekaligus sebagai penanda bahwa sampah plastik yang berasal dari limbah kegiatan manusia pun telah menjangkau sudut-sudut terpencil di dunia.Berdasarkan studi literatur, artikel ini menyajikan penyebab-penyebab limbah plastik dan ragam penanganannya. Analisis diinformasikan oleh teori konsekuensi modernitas yang dikemukakan oleh Anthony Giddens (2000, 2001, 2009). Pada bagian akhir tulisan, akan dikemukakan jalan yang dapat ditempuh untuk mengurangi masalah sampah plastik tersebut.

Plastik telah menjadi bagian integral dan penting dari masyarakat di seluruh dunia, termasuk Indonesia. Material plastik yang mudah dibuat ke dalam berbagai bentuk dan kuat namun ringan, serta tahan air, tahan lama dan murah menjadikannya mengantikan material lain seperti, metal, kaca, kayu, dan karet alam. Karena itu, plastik dimanfaatkan untuk hampir semua keperluan hidup manusia, seperti untuk kemasan, alat-alat rumah tangga, kegiatan pertanian, bagian dari barang elektronik dan kendaraan bermotor, peralatan medis dan sebagainya. Proses fabrikasi plastik dapat dimodifikasi ke dalam berbagai bentuk, warna, dan spesifikasi, menurut kebutuhan konsumennya (Singh dan Devi, 2019). Pertanyaan yang akan dijawab adalah dalam artikel ini adalah bagaimana cara plastik menimbulkan masalah lingkungan? Masalah lingkungan apa yang ditimbulkan oleh plastik? Apa cara yang digunakan untuk menangani sampah plastik?

\section{Kerangka Teoritis}

\section{Konsekuensi modernitas}

Anthony Giddens melihat lingkungan hidup sebagai salah satu isu utama dan penting dalam sosiologi (2006: 939- 949). Ini antara lain, terkait dengan keberadaan dan dinamika pertumbuhan di negara-negara industry dan proses pembangunan dari negara-negara sedang berkembang. Giddens melihatnya dalam kaitan dengan konsep pembangunan berkelanjutan. Baginya pembangunan berkelanjutan mengandalkan sumber daya yang didaur ulang dan mampu menekan pencemaran pada tingkat yang minimal. Menurutnya, "Sustainable development means that growth should, at least ideally, be carried on in such a way as to recycle physical resources rather than to deplete them, and to keep levels of pollution to a minimum" (Pembangunan berkelanjutan berarti pertumbuhan harus, setidaknya idealnya, dilakukan sedemikian rupa untuk mendaur ulang sumber daya fisik daripada mengurasnya, dan untuk menjaga tingkat polusi seminimal mungkin).

Disamping mencermati masalah lingkungan lainnya seperti pemanasan global, deforestasi, degradasi lahan, dan berkurangnya pasokan air bersih, Giddens menaruh perhatian terhadap masalah sampah plastik. Tentang ini antara lain dia 
menulis, "Many kinds of plastic widely employed in food packaging simply become unusable waste; there is no way of recycling it, and it has to be buried in refuse tips where it remains for centuries(Banyak jenis plastik yang banyak digunakan dalam kemasan makanan menjadi limbah yang tidak dapat digunakan; tidak ada cara untuk mendaur ulangnya, dan itu harus dikuburkan di ujung sampah yang masih tersisa selama berabad-abad).

Giddens tidak meonal modernitas. Hal yang harus dilihat kemudian, kata Giddens, adalah pengelolaan sampah. Lebih lanjut Giddens melihat bahwa masalah sampah plastik di negara-negara berkembang terkait dengan sistem pengelolaan sampah yang buruk. Menurutnya, "In the developing world, the greatest problem with domestic waste at the present time is the lack of refuse collection services. It has been estimated that 20 to 50 percent of domestic waste in the developing world goes uncollected. Poorly managed waste systems mean that refuse piles up in the streets, contributing to the spread of disease. With the passing of time, it is very likely that the developing world will face problems with waste disposal that are even more acute than the current situation in the industrialized countries." Apa yang dinyatakan Giddens bahwa 20 sampai 50 \% dari dari sampah di negara-negara berkembang tidak terkumpul dan belum dikelola dengan baik, ini juga terjadi di Indonesia.

Giddens (2009: 83-84) menegaskan bahwa modernitas pada dasarnya mengglobal. Menurut Giddens (2001: 1-15), masalah sampah terkait pula dengan tatanan global tersebut. Globalisasi tidak berkembang secara adil, dan tidak berarti semua konsekuensinya menguntungkan atau baik. Di negara-negara berkembang, beberapa perusahaan transnasional mendirikan industri atau menjual produkproduk yang di negara maju sendiri sudah dibatasi atau dilarang. Ketika plastik sudah diregulasi dengan ketat di negara-negara maju dan relatif telah dapat mengontrol dan mengelola sampahnya dengan baik, negara-negara berkembang justru sedang aktif berproduksi dan mengkosumsinya, namun keteteran dalam pengelolaan sampahnya. Ini akan menjadi risiko ekologis paling serius yang akan dihadapi negara-negara berkembang, termasuk Indonesia.

Dalam masyarakat, ini terkait dengan ruang dan waktu dimana transformasi lokal dapat terjadi. Produksi plastik di kota misalnya, dapat berkonsekuensi pada relasi sosial di antara ibu-ibu pembuat lepat atau penganan yang biasa dibungkus daun pisang dengan petani yang biasa memasok daun pisang pembungkus makanan. Layanan pesan-antar makanan sebagian antara lain juga dimudahkan oleh keberadaan plastik sebagai pembungkus atau kemasan. Dapat dipahami, ini semua berimplikasi pada intensitas dan frekuensi relasi sosial dalam suatu komunitas, sembari menjadikan mereka secara tidak langsung terkoneksi dengan kapitalis produsen plastik. Akan tetapi, berkonsekuensi pula pada meningkatnya jumlah sampah plastik

\section{B. METODE PENELITIAN}

Artikel ini didasarkan pada hasil kajian literatur. Uraian akan didukung oleh data sekunder dari sumber resmi seperti Badan Pusat Statistik (BPS) dan referensi lainnya yang dikutip dalam artikel ini. 


\section{HASIL DAN PEMBAHASAN}

\section{Produksi Plastik Memenuhi Kebutuhan Masyarakat Modern}

Pertumbuhan fenomenal plastik akibat dari produksi plastik. Produksi plastik dalam skala industrial dimulai pada tahun 1940-an, semenjak itu diperkirakan terus tumbuh rata-rata 10 persen per tahun. Peningkatan produksi secaraglobal terjadi dari 1.3 juta ton pada tahun195menjadi sekitar 300 juta ton pada tahun 2014. (Muise et.al, 2016; Zmak, 2017).

\section{Perilaku Konsumsi Plastik Penyebab Sampah Plastik Merusak Lingkungan}

Karena tersedia di pasar, plastik dipergunakan oleh rumah tangga untuk memenuhi kebutuhannya. Akibatnya, jumlah dari sampah plastik meningkat seiring meningkatnya jumlah konsumsi plastik karena meningkatnya populasi dan aktivitas manusia (Witchai-utcha dan Chavalparit, 2019).

Di samping kantong plastik sekali pakai, sedotan plastik, kemasan makanan dan minuman seperti sachet mendominasi penggunaan plastik oleh rumah tangga dan ini terlihat dari volume sampah plastik jenis ini. Greenpeace tahun 2019, misalnya, melaporkan adanya 855 miliar sachet terjual di pasar global pada tahun ini, di mana $50 \%$ pangsa pasarnya adalah Asia Tenggara. Diprediksi jumlah kemasan sachet yang terjual akan mencapai 1,3 triliun pada tahun 2027 (https://www.greenpeace.org/usa/wp-content/uploads/report).

Tendensi di atas, sejalan dengan data dari Asosiasi Industri Plastik Indonesia (INAPLAS), bahwa konsumsi plastik nasional masih di dominasi oleh plastik kemasan yakni sekitar $65 \%$. Dari jumlah itu, 60 persen di antaranya diserap oleh industri makanan dan minuman. Seperti diketahui, industri makanan dan minuman adalah suatu sektor yang pertumbuhannya paling cepat di Indonesia.Pada semester satu 2019, misalnya, industri minumandi Indonesia tumbuh 22,74\% (https://www.greenpeace.org/indonesia/laporan/4230/krisis-belum-terurai).

Karena itu, menjadi dapat dimengerti ketika sektor industri makanan dan minuman ini terus tumbuh, maka volume sampah plastik di Indonesia juga akan terus meningkat.

Tambahan lagi, perilaku penggunaan plastik masih belum menggembirakan. Seperti yang dilaporkan BPS (2018), Survei Sosial Ekonomi Nasional (Susenas) tahun 2017 menunjukkannya melalui perilaku membawa tas belanja sendiri dan perilaku dalam mengelola sampah rumah tangga.

\section{Tidak Mendaur ulang Kantong Plastik}

Data Susenas ternyata menunjukkan bahwa terdapat 54,8 persen rumah tangga yang tidak pernah membawa tas belanja sendiri ketika berbelanja. Hanya 8,7 persen yang selalu membawa tas belanja sendiri ketika berbelanja; selebihnya 26,5 persen menyatakan kadang-kadang, dan 9,9 persen menyatakan sering.

Data itu diperkuat pula oleh data Susenas yang menunjukkan bahwa masyarakat juga belum berpartisipasi secara positif dalam mengelola sampah yang dihasilkan, misalnya dengan mendaur ulang atau membuang sampah ke tempat yang tidak menimbulkan polusi atau masalah baru. Hasil Susenas menunjukan hanya 1,2 persen rumah tangga yang melakukan kegiatan daur ulang. 


\section{Perilaku Mengelola Sampah:Membuang Sampah Plastik ke Selokan}

Banyak orang membuang sampah plastik sembarangan, bahkan membuang ke selokan/sungai. Perbuatan memperlakukan sampah plastik seperti itu menimbulkan pencemaran dan dampak negative terhadap, lingkungan seperti banjir dan pencemaran laut.World Economic Forum pada tahun 2016 menyatakan ada lebih dari 150 juta ton plastik. Setiap tahun, diperkirakan 8 juta ton plastik mengalir ke laut. Sementara itu, Jambeck et.al (2015) menyatakan ada 275 juta ton sampah plastik di 192 negara berpantai tahun 2010. Dari jumlah itu diperkirakan sekitar 4,8 - 12,7 juta ton mengalir ke lautan di seluruh dunia.

Indonesia sendiri merupakan negara dengan jumlah pencemaran sampah plastik ke laut terbesar kedua di dunia. Cina berada pada urutan pertama dengan sampah plastik ke laut sekitar 1,23 - 3, 53 juta ton/tahun. Indonesia, dengan jumlah populasi pesisir sebesar 187,2 juta orang menghasilkan 3,22 juta ton sampah plastik yang tidak terkelola dengan baik. Dari jumlah itu, 0,48-1,29 juta ton di antaranya diperkirakan mencemari lautan.

Padahal, jumlah penduduk pesisir Indonesia hampir sama dengan India yaitu sekitar 187 juta jiwa. Namun, di India tingkat pencemaran plastik ke laut hanya sekitar 0,09 - 0,24 juta ton/tahun dan menempati urutan 12 dunia. Data ini mengindikasikan bahwa sistem pengelolaan sampah Indonesia belum baik. Sehubungan dengan itu,, studi yang dilakukan Hidayat et.al (2019), misalnya, menunjukkan bahwa pengelolaan sampah plastik di Indonesia memang masih kurang efektif.

\section{Kurangnya Sarana Pendukung Penanganan Sampah Plastik}

Selain masalah perilaku di atas, dalam penanganan sampah, termasuk sampah plastik, sarana dan prasarana pendukung yang memadai amat diperlukan dan penting diperhatikan. Jumlah penduduk dan aktivitas yang semakin meningkat di perkotaan perlu diikuti sarana dan prasarana penanganan sampah atau kebersihan yang semakin banyak dan lengkap. Realitasnya, data BPS (2018) menunjukkan sarana penanggulangan sampah dan kebersihan kota di sebagian besar ibukota provinsi di Indonesia tahun 2016 - 2017 cenderung stagnan. Karena itu, misalnya, volume sampah yang terangkut per hari pada kota ibukota provinsi di Indonesia baru mencapai $71,28 \%$.

Kekurangan sarana pendukung akibat dari rendahnya alokasi dana APBD untuk bidang Lingkungan Hidup yang notabene juga termasuk untuk pengelolaan sampah pada masing-masing provinsi. Jika pada tahun 2013 rata-rata nasional alokasi APBD untuk lingkungan hidup adalah 0,85\%, maka pada tahun 2017 justru turun menjadi 0, 65 \%. Pada tahun 2017 yang paling tinggi alokasi APBD-nya untuk lingkungan hidup adalah Provinsi Kalimantan Selatan. Sedangkan Provinsi Sumatera Barat masih berada di bawah rata-rata nasional yakni 0, $35 \%$.

\section{Dampak Sampah Plastik}

Seperti yang telah disinggung sebelumnya di Indonesia sekitar $30 \%$ sampah tidak terkelola dengan baik dan hanya 1,5\% yang didaur ulang. Selain itu, sampah plastik juga potensial menimbulkan penyakit paru dan saluran pernafasan melalui polusi pembakaran limbahnya. 
Di samping itu, potensi ancaman kesehatan manusia juga berasal dari mikroplastik. Sampah plastik di lautan lambat laun akan menyerpih dan terurai menjadi mikroplastik. Menurut Notohamijoyo dalam Media Indonesia (27 Juni 2020) mikroplastik tersebut akan tertelan hewan laut dan di dalam tubuhnya akan terjadi translokasi dari saluran pencernaan ke dalam otot. Cemaran mikroplastik dalam tubuh hewan laut itu membahayakan bagi konsumsi manusia. Diperkirakan $25 \%$ dari spesies ikan yang dimakan di Indonesia mengandung mikroplastik. Distribusi mikroplastik ini sudah ditemukan diberbagai perairan laut Indonesia.

Dalam bentuk lain, pada masa pandemi Covid-19, ancaman kesehatan dari plastik terjadi juga secara tidak langsung. Hasil penelitian Doremalen et.al (2020) virus corona dapat menempel lebih lama pada plastik ketimbang di udara dan material lain. Virus corona yang keluar melalui tetesan (droplet) akibat batuk atau bersin dapat bertahan dan menjadi airborne di udara selama lebih kurang 3 jam. Tetesan tersebut berukuran sekitar 1 hingga 5 mikrometer atau 30 kali lebih kecil dari lebar rambut manusia. Kalau tetesan tersebut menempel di kardus atau karton, virusnya akan bertahan hingga 24 jam, dan pada permukaan tembaga virus bertahan hingga 4 jam. Akan tetapi, pada permukaan plastik dan stainless steel virus dapat bertahan lebih lama lagi yakni 48-72 jam. Mengingat plastik banyak dipakai dalam berbagai aktivitas manusia, dapat dibayangkan potensi penularan virus ini melalui media permukaan plastik.

Dari kaca mata Giddens, sampah plastik ini adalah salah satu dari berbagai masalah dunia yang sedang tunggang-langgang (runaway world). Plastik merupakan gejala modernitas yang berlarian tunggang-langgang. Kapitalisme dan industrialisasi adalah pilar penyangga modernitas yang bertanggungjawab terhadap lonjakan konsumsi dan sampah plastik. Sampah plastik yang bertebaran dan juga mengapung di lautan seluruh dunia dapat dilihat sebagai penanda yang melambangkan globalisasi.

Masalah sampah plastik sebagai konsekuensi modernitas juga masuk melalui kemasan (packaging). Kapitalisme dan industrialisasi yang menopang modernitas menekankan pentingnya kemasan dalam setiap produknya. Sebagian besar kemasan adalah berbentuk plastik. Bahan plastik yang mudah dibentuk, ringan, tahan air dan murah menjadikannya pilihan yang paling efisien dan rasional untuk kemasan. Tidak itu saja, menurut Giddens (2001: 949) kemasan itu menjadikan produk itu lebih atraktif. Produk yang dikemas dengan menarik tentu akan mendorong lagi orang untuk berbelanja atau menjadi konsumtif dan ini memutar roda kapitalisme. Karena itu, kemanapun kita pergi belanja, ke supermarket, toko mainan, restoran cepat-saji, toko buku dan sebagainya, maka hampir semua produk atau barangnya dikemas dengan plastik. Di supermarket di kota-kota besar bukan hanya barang-barang produksi pabrik yang dikemas dengan plastik, namun juga hasil pertanian berupa produk nabati dan hewani. Lebih jauh Giddens menyatakan: "Although there are clear benefits to packaging in terms of displaying goods attractively and guaranteeing the safety of products, there are enormous drawbacks ad well. One of the clearest indicators of increasing consumption is the growing amount of domestic waste,...The industrialized societies have sometimes been called 'throw away societies' because the volume of items discarded as a matter of course is so large. 


\section{Upaya Penanggulangan Sampah Plastik}

Pada bagian ini akan dicoba sajikan upaya penanggulangan yang dapat dilakukan dengan tetap menggunakan kerangka pemikiran Giddens. Menurut Giddens (2009: 178-181) masyarakat selalu memiliki reaksi adaptif terhadap profil risiko modernitas. Demikian pula, terhadap masalah sampah plastik sebagai profil risiko modernitas, dapat dijelaskan 4 reaksi adaptif yang mungkin muncul dalam masyarakat.

Pertama, penerimaan pragmatis yang biasanya muncul pada masyarakat awam yang melihat plastik dari sisi kegunaanya saja dan merupakan produk yang tidak mungkin dihindarkan. Reaksi adaptif kedua, adalah optimisme abadi, yang memandang bahwa penggunaan plastik dapat dikontrol dan sampahnya juga dapat dikelola dengan baik. Berlawanan dengan yang kedua, reaksi adaptif ketiga adalah pesimisme sinis yang memandang sulit untuk melepaskan diri dari ketergantungan terhadap plastik. Reaksi adaptif keempat adalah adalah keterlibatan radikal, yakni mereka yang langsung terjun bergerak di tataran praksis untuk mengurangi dan mengelola sampah plastik.

Sekaitan dengan itu, Giddens (2003: 132-140) sendiri melihat sebagai tidak perlu pesimis. Menurutnya diperlukan manajemen ekologis global dimana ketidaksaling bersesuaian antara perkembangan ekonomi dan manajemen ekologis yang ketat tidak perlu dirisaukan lagi. Dalam hal ini diperlukan orientasi baru terhadap modernisasi ekologis dengan mendorong inovasi yang memungkinkan produsen untuk bertindak secara lebih efisien dan produktif. Ini berarti perlu digencarkan riset dan produksi plastik yang lebih masif dengan bahan yang lebih mudah terurai dan ramah lingkungan.

Bagi Giddens, secara ekologis polusi merupakan bahaya yang sekaligus merupakan bentuk kesia-siaan ekonomi. Adanya kesia-siaan menandakan bahwa produsen dan otoritas terkait sebagai pelaku (agency) tidak mengelola sumberdaya secara sempurna dan efektif di hadapan struktur yang ada. Pengendalian terhadap pencemaran pada program-program ekologis justru membutuhkan biaya-biaya tambahan karena dilakukannya proses pembersihan. Selain itu, ada lagi yang penting yang tidak mudah untuk menghitungnya, yakni social cost yang langsung atau tidak langsung dipikul masyarakat akibat pencemaran itu.

Dengan penekanan pada produksi yang lebih inovatif maka akan terbentuk ekonomi baru dimana daur ulang menjadi solusi. Dalam hal ini proses produksi pada seluruh industri harus aktif dan intensif untuk mencapai tujuan tanpa sampah. Sebagai contoh, Toyota dan Honda melakukan daur ulang hingga mencapai tingkat $85 \%$ untuk bagian-bagian mobil yang mereka produksi. Ini berarti sampah bukan lagi sampah, tapi sumber bagi industri yang inovatif. Dengan demikian, proses ekonomi baru yang menghasilkan lebih banyak dari bahan yang sedikit itu memiliki implikasi lingkungan yang berbeda.

Terkait dengan ekonomi baru yang bersifat sirkuler itu, maka perusahaan dan industri perlu melakukan banyak kerjasama dengan pihak lain seperti badan-badan pemerintah dan masyarakat. Mereka perlu berkerja sama agar dapat secara sinergis mencegah dan membatasi polusi sampah plastik sebelum terjadi. Insentif berupa dana CSR bagi kelompok-kelompok masyarakat yang peduli terhadap sampah plastik adalah penting dan diperlukan. Dana CSR itu dapat,digunakan untuk 
berbagai kegiatan yang suportif terhadap pencegahan dan pengurangan sampah plastik.

Otoritas-otoritas publik terkait seperti Kementerian dan Dinas Lingkungan Hidup mesti aktif dan proaktif dalam upaya tersebut. Mereka harus mengambil peran sentral dan bertanggungjawab dalam pengambilan keputusan yang relevan. Mereka tidak hanya merespon dari dinamika yang ada dan risiko-risiko yang mungkin timbul. Posisi otoritas-otoritas publik tersebut adalah strategis dalam jaringan kerjasama di antara para pihak (stakeholders) dalam penanggulangan sampah plastik.

Bagi Giddens struktur sebagai sarana (medium dan resources) juga bersifat memberdayakan (enabling) dimana dimungkinkan dilakukannya praktik-praktik baru (Priyono, 2002: 23-29). Sehubungan dengan itu, upaya komunikasi, informasi, dan edukasi terkait pemanfaatan dan pengelolaan sampah plastik yang ramah lingkungan perlu terus dan gencar dilakukan. Kampanye 3R (Reduce, Reuse, Recycle) di kalangan produsen dan konsumen yang sistematis dan masif perlu disertai dengan contoh praktik-praktik baru.

Gaya hidup ramah lingkungan (go green) perlu dikembangkan secara luas. Tindakan membawa tumbler, misalnya, perlu dibiasakan sehingga mengurangi konsumsi air kemasan. Selain itu, tindakan untuk tidak menggunakan sedotan plastik serta membiasakan membawa tas belanja sendiri akan mengurangi jumlah sampah plastik. Di level rumah tangga, juga perlu dibiasakan pemilahan sampah, sehingga sampah plastik mudah diproses untuk didaur ulang.

Semua praktik-praktik baru di atas, dalam lensa Giddens, idealnya berkembang dalam diri pelaku (agency) dari motivasi tak sadar (unconscious motives) menjadi kesadaran praktis (practical consciousness) dan seterusnya menjadi kesadaran diskursif (discursive consciousness). Dengan motivasi tak sadar tindakan membawa tumbler ke kantor atau sekolah mungkin hanya sekedar ikut-ikutan tanpa niat yang jelas untuk ikut mengurangi sampah plastik. Namun, dengan kesadaran praktis, maka tindakan membawa tumbler menjadi ada landasan ontologisnya, karena berdasarkan pengetahuan untuk ikut menjaga lingkungan dari pencemaran sampah plastik. Terakhir, sangat baik kalau pelaku memiliki kesadaran diskursif, dimana mereka memiliki kapasitas untuk mengerti dan merefleksi serta mampu menjelaskan arti dari semua tindakan mereka yang ramah lingkungan.

\section{KESIMPULAN}

Walaupun sangat bermanfaat, plastik telah merusak lingkungan akibat perilaku penggunaan dan plastik dan buruknya pengelolaan sampah secara umum. Penyebab sampah plastik ada yang dihukum dan ada yang di hilir. Pertumbuhan plastik akibat dari produksi plastik untuk memenuhi kebutuhan masyarakat modern adalah penyebab sampah plastik di hulu, sedangkan perilaku penggunaan plastik merupakan penyebab di hilir. Karena itu, pengurangan dampak sampah plastik memerlukan tindakan di hulu (produksi plastik) dan di hilir (konsumsi) plastik. 


\section{E. UCAPAN TERIMAKASIH}

Penulis mengucapkan terimakasih kepada para pihak yang telah memberikan dukungan baik secara moril ataupun materil.

\section{F. DAFTAR PUSTAKA}

Badan Pusat Statistik. 2018. Statistik Lingkungan Hidup. Jakarta: BPS Culin, Julena dan Tom Belic. 2015. Plastic Pollution from Ships.

Drucker, Peter F.1997. Masyarakat Pasca Kapitalis. Bandung: Angkasa,

Doremalen, Neeltje van,, et.al. 2020."Aerosol and Surface Stability of SARS-CoV-2 as CompareWith SARS-CoV-1", The New England Journal of Medicine.

Giddens, Anthony. 2000.Jalan Ketiga dan Kritik-kritiknya.Yogyakarta:Ircisod

Giddens, Anthony. 2001.Runaway World: Bagaimana Globalisasi Merombak Kehidupan Kita.Jakarta: Gramedia Pustaka Utama.

Giddens, Anthony. 2005.Konsekuensi-konsekuensi Modernitas.Bantul:Kreasi Wacana.

Giddens, Anthony. 2006. Sociology, Polity Press, Cambridge.

Haggar, Salah el dan Lama el Hatow. 2009. "Reinforcement of throw plastic rejects in production manhole covers". Journal of Cleaner Production, Vol. 17.

Herry-Priyono, B.2002.Anthony Giddens: Suatu Pengantar. Kepustakaan Populer Gramedia.

Hidayat, Yosi Agustina et.al. 2019. “A Study of plastic word management effectiveness in Indonesia industries", AIMS Energy, Vol. 7.

Jalil, Md Abdul, “Using Plastic Bags and Its damaging Impact on Environment and Agriculture",

Jambeck, Jeena R., et,al. 2015. " Plastic waste inputs from land into the ocean". Science. Kompas, 24 Juni 2020.

Muise, Isaac, et.al, "Attitudes to recovery and recycling of agricultural plastics waste: A case study of Nova Scotia, Canada", Resources, Conserrvation, Recycling, Vol. 109, 2016.

Notohamijoyo, A., "Bahaya Plastik terhadap Kelestarian Laut”, Media Indonesia, 27 Juni 2020.

Singh, Anil Pratap, dan Angon Sarjubala Devi. 2019. “Plastic Waste Management: a Review", International Journal of Advanced Scientific Research in Management, Vol4.

U. Mahesha, dan Mallika Pinawale. 2017.“Problem of Solid Waste in Srilanka and Existing Management Strategies".EPRA International Journal of Research and Development, Vol. 2.

Wichai-utcha N, dan O. Chavalparit. 2019. “ 3Rs Policy and plastic waste management in Thailand", Journal of Material Cycles and Waste Management.

https://www.greenpeace.org/usa/wp-content/uploads/report Diakses 27 Juni 2020.

https:/ / www.greenpeace.org/indonesia/laporan/4230/krisis-belum-terurai.

Diakses 27 Juni 2020. 